\title{
ARHGAP45 NM_012292.4:C.416G>A
}

National Cancer Institute

\section{Source}

National Cancer Institute. ARHGAP45 NM 012292.4:C.416G>A. NCI Thesaurus. Code C157548.

A nucleotide substitution at position 416 of the coding sequence of the ARHGAP45 gene where guanine has been mutated to adenine. 